\title{
Regional Integration: \\ A Political Federation of the East African Countries?
}

\section{Phillip Apuuli Kasaija*}

\begin{abstract}
The aim of this paper is to explore the possibility and viability of an East African political federation project. Since the late 1800s under the then British East Africa, the countries of East Africa have been searching for ways to integrate. The search led to the establishment of the East African Community (EAC) in December 1967, which later collapsed in 1977. The argument of the paper is that it appears that among the current crop of leaders of the region there is the political will to establish the East African federation. However, it will take more than political will to bring the federation to fruition, as conditions in the region currently do not augur well for the project. Also, the leaders have not carried the people along with them on the integration journey. One main problem of attempts at integration in East Africa in particular and Africa in general, has been that they have been leader-led. Whether it was the Organisation of African Unity (OAU) or now the African Union (AU), the people at the grassroots have played no role in their establishment and consolidation. The question therefore is: Do existing conditions in the region advance the project of an East African federation?
\end{abstract}

\section{Résumé}

L'objectif de cet article est d'étudier la possibilité et la viabilité du projet d'une fédération politique est-africaine. Depuis la fin des années dix-huit cent, dans l'Afrique de l'Est britannique de l'époque, les pays de la zone cherchent des moyens d'intégration. Cette quête a conduit à la mise en place de la Communauté EstAfricaine (CEA) en décembre 1967, qui a été dissoute en 1977. L'argument avancé par cette contribution est qu'il paraît clair que les actuels dirigeants de la région

* Department of Political Science and Public Administration, Makerere University, Kampala, Uganda. 
expriment une volonté manifeste de mettre sur pied la fédération est-africaine. Cependant, il faudra bien plus qu'une simple volonté politique pour mûrir un tel projet de fédération. Les conditions actuelles de cette région n'augurent rien de bon pour la création de ce projet. En outre, les dirigeants n'ont pas consulté les populations dans le cadre de cette intégration. Le problème des processus d'intégration en Afrique de l'Est particulièrement et en Afrique de manière générale, est que ceux-ci sont monopolisés par les dirigeants. Par exemple, le citoyen lambda n'a joué aucun rôle dans l'établissement et la consolidation de l'Organisation de l'Unité Africaine (OAU), aujourd'hui Union Africaine (UA). Il convient donc de se poser la question suivante : les conditions actuelles de la région permettent-elles de faire avancer le projet d'une Fédération Est-Africaine?

\section{Introduction}

In July 1998, President Yoweri Museveni of Uganda presented a paper entitled 'Towards a closer cooperation in Africa' at the ruling National Resistance Movement's (NRM) National Conference. Clearly the paper was aimed at domestic as well as regional audiences. In the paper Museveni argued, among other things, that if the countries of East and Central Africa are to play a meaningful role in this era of globalisation, they had to think of moving towards a political union. He suggested that the countries of the East Africa Community (EAC) together with Rwanda and Burundi must federate politically in order to command respect from the other countries of the world. The federation would also enhance their bargaining strength in multi-lateral institutions, as well as bilaterally.

At the time of Museveni's speech, the East African Community revival draft treaty was being debated by the public in the three East African countries. The draft treaty contained a provision which called for the three partner states to move towards a political federation. After the signing of the East African Community Treaty, the call to establish a political federation of the three states has been taken up by the East African Legislative Assembly. The debate was launched in Nairobi in June 2002, when the Assembly held its session in Kenya. The coming to power of the National Rainbow Coalition (NARC) government in Kenya in December 2002, further galvanised the voices that are in favour of moving towards the political integration of the EAC. President Mwai Kibaki, like Museveni, is in favour of the project.

The aim of this paper will be to explore the possibility and viability of the project of an East African political federation. Since the late 
1800s under the then British East Africa, the countries of East Africa have been searching for ways to integrate. The search led to the establishment of the East African Community (EAC) in December 1967, which later collapsed in 1977. The argument of the paper is that it appears that there is the political will to establish the East African federation among the current crop of leaders of the region. However, it will take more than political will to bring the federation to fruition. The conditions existing in the region currently do not augur well for the project.

Also, the leaders have not carried the people along with them on the integration journey. The problem of the integration process in East Africa in particular and Africa in general, has been that it has been leaderled. Whether it was the Organisation of African Unity (OAU) or now the African Union (AU), the common man has played no role in their establishment and consolidation. The question therefore is: Do conditions that exist in the region advance the project of an East African federation?

\section{Conceptualising the Terms}

According to the East African Community Treaty, the EAC intends to achieve a political federation starting with a common market and a monetary union. Therefore at the moment, the cooperation between the three East African countries can be categorised as being in a state of becoming, which in the long run is aimed at achieving a political federation (Mukandala 2000:89). In other words, the integration process in East Africa is to be achieved incrementally. The argument has always been whether the logical conclusion of any integration process is political or economic unity. The jury is still out.

Ben Belassa identified five ideal types of integration (Ojo et al. 1985:145). He stated that at the lowest level there is the free trade area in which tariffs and quotas are eliminated among the members of the integrating region. A customs union involves the elimination of tariffs and quotas, and also eliminates discriminatory tariffs by non-member countries, by setting up common external tariffs. The third level of integration involves the establishment of a common market. This entails the elimination of obstacles for the free flow of the factors of production, namely labour and capital. The fourth level is the establishment of an economic community or union, entailing the harmonisation of economic policies which may involve the introduction of a common 
currency. The highest form of integration is a political union, where the structures and political institutions which harmonise policies also themselves become harmonised and unified. The integration of East Africa aims at not following Belassa's typology as a straight jacket. Rather, it aims at achieving political federation by first establishing a customs union, and then following with a monetary one.

But what is political federation? Federalism refers to a political organisation in which two or more states agree to form a union government with central authority, while retaining local autonomy (Ojo et al. 1985:75). At the regional level however, federalism is the call for the coming together of independent nation states to form a federal government (ibid). In regional integration, political federation is a mean between political cooperation and political union. Political cooperation involves mutual policy arrangements among member states aimed at attaining common interests and objectives (Mukandala 2000:89). Political cooperation does not necessarily require the surrendering of one's jurisdiction to a central unit. A political union is the ultimate goal of cooperating parties, and entails a shared political jurisdiction in which the parties to the union agree to surrender either all or part of their sovereignty to a central political unit (ibid). In between political cooperation and political union is political federation. Political federation is a union of groups, united by one or more common objectives, but retaining their distinctive group character for other purposes (ibid). Each member state retains its distinctiveness in its own sphere. As a step towards achieving a political federation, the treaty of the EAC calls upon the partner states to establish a common foreign and security policy. ${ }^{1}$ But is political federation or union possible? Suffice to note that the European countries that have been building the European Union are still grappling with the whole question of political cooperation.

\section{East African Integration: The History}

Attempts at integrating the region started in the latter years of the 19th century. Moves to integrate East Africa were initiated by the British in 1894 with the decision to start the construction of the Uganda Railway. Ostensibly at the time, the British were not aiming at the integration of the region. Rather, the railway was to be used to transport raw materials for use in British industries. They did not know however that this venture would prove to be the first step that would help in fostering a process of integration of the region in the years to come. 
The process of integration of East Africa can clearly be divided into four periods. The present attempt that began in 1984 can be said to be the fourth. The other three periods covered the years 1894-1947, 19481966, and 1967-1977. As we have already said, the British inadvertently set in motion the integration process of the region when they decided to construct the Uganda railway from Mombasa, Kenya in 1894. The construction work actually began in 1895. Later on, they began promoting efforts to advance a more unified administrative control over their East African territories by establishing the Court of Appeal for East Africa in 1902, a Postal Union in 1911, a Customs Union in 1917, and the East African Currency Board in 1920 (Ojo et al. 1985:157). Tanganyika which became a British Mandate after the First World War, and which later merged with Zanzibar to become Tanzania, was gradually absorbed into these institutions by 1963. This was the first period of integration of East Africa. Commenting on the moves to integrate the region during this period, Ibrahim Gambari asserted that:

[s]kewed as it may have been in favour of the settler community in Kenya, economic cooperation was an early fact of life in the sub-region. In 1917, the Kenya and Uganda protectorates merged their custom authorities, common tariff rates between Kenya and Uganda were also extended to Tanganyika in 1922. By the following year, the three countries engaged in free trade for local produce. This was followed by an agreement which removed almost all custom duties between the three territories.(Ademola 1999:90-1)

The second period began in 1948, when a quasi-federation was established with a common market and a number of common services (ibid). The common services included the establishment of an East African Railway and Harbours Administration, the East African Posts and Telecommunications Administration, and the Agricultural and Medical Research Services (ibid). A High Commission, comprising of the three territorial governors, ${ }^{2}$ with a Secretariat manned by technocrats with a region-wide outlook and expertise, coordinated the common services. There also existed a central legislature called the East Africa Central Legislative Assembly, although only with limited powers. Commenting on the integration of the region at this time, Mukandala-Rwekaza has noted that:

[t]his was a political cooperation whose scope was limited only to providing the critical support and context for economic cooperation. It was not expected to develop and evolve into something qualitatively differ- 
ent like a political federation or union. There was never the possibility that the three governments could go to war against each other, or could undermine each other... the three governments were unified in philosophy, purpose and strategy. Thus their value was mutually compatible (Mukandala2000:95).

No doubt that this period was the golden era of East African integration. In 1961, the quasi-federation was revamped with the attainment of independence by Tanganyika. The other reason for the revamping came from the resentment that Uganda and Tanganyika expressed at the disproportionate benefits accruing to Kenya in terms of growth in GNP, foreign investment, international trade, and the location of the common services headquarters in Nairobi (Ojo et al. 1985:157). The location of the common service headquarters in Nairobi was to remain a sore point of contention. Suffice to note that an East African Common Services Organisation (EACSO) had been established, as a prelude to the establishment of a fully fledged political federation of the region.

This period of integration was tempered by the attainment of independence by the three countries of East Africa. A political federation of the three independent countries was to be ushered in by the Nairobi Declaration of 1963, but this was not to be. Uganda was opposed to the high degree of centralisation, which its partners wanted to build into the federation (ibid: 158). Also, as it has been noted, the ruling regimes in the three countries were engaged in intensive battles for political domination and hegemony at the time... [thus] challenges of nation building and regime consolidation demanded a national focus [and not a regional one] (Mukandala 2000:95). The situation pertaining then impelled Mwalimu Nyerere to write in the following terms:

a federation of at least Kenya, Uganda and Tanzania should be comparatively easy to achieve. We already have a common market, and run many services through the common services organisation which has its own central legislative assembly and an executive composed of the Prime Ministers of the three states. This is the nucleus from which a federation is the natural growth.(Ademola1999:91)

The quasi-federation that began in 1948 culminated in the establishment of the East African Community in December 1967. However, this was preceded by four landmark events in the history of East African integration. First, in 1963, the East African Federation Treaty was nearly signed in Arusha by the three presidents, but the agreement was 
aborted. This was for reasons we have just stated above. Second, in 1964, an agreement was signed in Kampala on the distribution of industries in the three partner states. This agreement called the KampalaMbale agreement provided that certain industries such as tyres, bicycle parts and fertilizers, be exclusively located in Uganda and Tanzania. Kenya failed to ratify this agreement. Third, in 1965-6, the East African Currency Union came to an end. As a result, three separate central banks were set up and started issuing national currencies. Fourthly, in 1966, a Commission made up of three Ministers and headed by a UN expert Kjeld Phillip, was appointed and tasked with negotiating a permanent solution to the problems that were afflicting East Africa's integration (Ojo et al. 1985:158). It recommended the establishment of the East African Community.

The third attempt at regional integration of East Africa began on 1 December 1967, with the coming into force of the Treaty for East African Cooperation. This experiment ended in failure in 1977. However, the treaty was significant in many ways. First, it placed the common market and the common services within one framework, and also gave the former a solid legal foundation (ibid). Secondly, it made provisions aimed at achieving equitable distribution of cost and benefits. Thirdly, a new innovation was made. The treaty created a number of community organs to coordinate activities and also give executive direction. In this regard, it provided for a Community Minister who was appointed by each state to promote the Community's interests and project its viewpoints in his or her own cabinet (ibid). This experiment at integration failed in 1977 for various reasons. ${ }^{3}$

However, it should be noted that the time the EAC was in existence, it was one of the most advanced integration schemes in Africa. In fact it has been said that the EAC effort was the most advanced regional idea at integration in the whole of the developing world (Ademola op cit:90).

The latest attempt to reconstruct the sub-region into a viable integration group began in 1984 when the three countries signed the East African Community Mediation Agreement for the Division of Assets and Liabilities ${ }^{4}$ of the defunct EAC (Mukandala 2000:97). In this agreement, the partner states committed themselves to exploring areas of future cooperation. However, concrete moves towards the revival of the Community did not begin until November 1991, when the three heads of state held a summit in Nairobi, after which they issued a formal communiqué committing themselves to revive the East African Coop- 
eration (Tulya-Muhika 2000:37). A committee of Foreign Ministers was set up to work out the details. Two years later, in November 1993, the heads of state set up the Permanent Tripartite Commission after a meeting in Arusha, Tanzania. A year later, in November 1994, the first protocol to establish an EAC Secretariat in Arusha, was signed in Kampala. The Secretariat was finally established in March 1996, and Ambassador Francis Muthaura was appointed its first Executive Secretary.

The draft Treaty for the establishment of the EAC was published in 1998, after which it was circulated in the three countries for debate. After the debates in the partner states, the heads of state finally signed the treaty into force on 30 November 1999. As we write, most of the institutions that were provided for under the treaty are up and running. These include the Secretariat, the East African Legislative Assembly (EALA), and the East African Court of Justice.

\section{Museveni's Arguments}

Amid the debate on the draft treaty of the EAC, President Museveni came out with his own views. We will restrict ourselves to only those that pertain to the integration of East Africa. In his paper, that we mentioned in the introduction, he advanced a number of arguments. First, he averred that economic integration is not enough because of political fragmentation. There is a lack of a political superstructure necessary for the integration process. Given the present economically weak states, there is no single African state that can impose discipline on the others by economic or other forms of pressure. He compared Africa to the Western hemisphere, where the United States plays a head prefect role due to its economic and military might. Museveni concluded that Africa lacked a head prefect because of political fragmentation. Therefore, he was making a case for African political integration.

Secondly, he argued that a Union of Central and Eastern Africa states would command more respect from the world. An investor would be more attracted to invest in a united East Africa than in just Uganda because of the bigger market the former offers', he argued.

Thirdly, a union would command more defence potential to guard African interests against encroachment by foreigners. He argued that 'the present small African states individually, do not possess much defence capacity'.

Fourthly, he averred that there were already basic unity or linkages in Africa. He gave the example of East Africa where there are linkages of 
languages and culture. He cited the example of the Luo language which is spoken by the Nilotics, who are found in Kenya, Uganda, Sudan, Tanzania and parts of Ethiopia and the Democratic Republic of Congo (DRC). In terms of culture, he argued that the Bantu culture straddles East, Central and Southern Africa.

President Museveni further argued that Africa must create a centre of gravity, just like the USA is a centre of gravity for Anglo-Saxon-Latin civilisation. He said that the countries that would establish the initial vanguard of the Union would be Uganda, Kenya, Tanzania, Rwanda and Burundi. The advantage of these countries is that they are geographically contiguous and share to a certain degree a common language (Swahili) and culture. Other countries would be encouraged to join, as long as they were geographically contiguous to the Union.

According to Museveni the union would be that of East and Central African states. Power would be shared between the Union government and the national governments. The Union government would be responsible for external defence, foreign affairs, common market affairs, common services - such as railways, harbours and posts and telecommunications, and scientific research. The national governments would share responsibility with districts in the areas of justice, education, health, internal security, roads, wildlife and tourism, agriculture, etc.

When circulated in the regional capitals, Museveni's paper was greeted with consternation. Commenting on it, Akiiki Mujaju noted that:

Museveni... has been acting like a leader on the campaign trail... the latest evidence of this was a document which he circulated recently advocating a political union of East African states including Rwanda and Burundi... his role in the Tutsi dominated Rwanda and Burundi and now his intervention in the DR Congo cast him in the image of a new Nkwame Nkrumah. ${ }^{5}$

It has to be remembered that when the African countries were debating ways on how they would integrate in the late 1950s, the then leader of Ghana, Nkwame Nkrumah, argued that African countries should right away integrate politically. In his own words, 'seek ye the political kingdom and the rest will follow'. However, the majority of the African countries rejected this view. Some leaders saw Nkurumah as wanting to become the president of Africa. In calling for political federation of East and Central African states, some quarters thought that now Museveni wanted to become the leader of the region! But, however 
much Museveni's views are disdained, he is the first leader in the region to come out with a clear view of what shape and form the federation of the region should take.

The issue of political federation has now been firmly put on the agenda of the EAC. The EALA has been debating the matter. ${ }^{6}$ The problem however is that the treaty does not define what a political federation of the region would eventually be. ${ }^{7}$

\section{Problems Militating Against the Ideas of Museveni and the Federation}

As we write, the partner states of the EAC are moving ahead to establish a customs union by the end of this year. This is the first step towards establishing the political federation. On the surface, it looks like achieving a political federation for the region would be easy, as all three governments of Kenya, Uganda and Tanzania are democratic. The economies of the countries of the region to some degree are already integrated. The total market that the region would command in a political/ economic union would be close to 90 million people. If Rwanda and Burundi were added, then the market would grow to more than 100 million. In principle, the latter two countries have applied to join the EAC as partners. In fact, Rwanda's application has been pending since 1999. Suffice to note that it has had an observer status in the EAC since 1994. The final admission of Rwanda into the EAC as a full partner has been delayed until the Community has established a custom union later this year. However, we would like to argue that the politics of the region and other inherent problems would severely hinder the advancement of Museveni's suggestions and also of the political federation idea.

First, internally the majority of the countries of the region generally are not stable. In Museveni's Uganda, an internal rebellion of the dissident Joseph Kony and his ilk of the Lord's Resistance Army (LRA) has been waging a war in Northern Uganda since 1986. This war has gone on for such a long time that it is very difficult to say when it will end. Increasingly, the conflict has taken on ethnic undertones. Some see the conflict as pitting the Nilotic northerners against Bantu southerners. Museveni and Kagame's military adventures in the Democratic Republic of Congo (DRC) have also been singled out as destabilising the region. 
Despite the recently held elections, which saw the overwhelming election of Paul Kagame as president, ethnic tensions remain in Rwanda. Matters have not been helped by the continued marginalisation of the majority Hutus by the minority Tutsi dominated government of the Rwandese Patriotic Front (RPF). Burundi has been in turmoil since 1993, when the first popularly elected Hutu president was brutally assassinated by the Tutsi dominated Burundi army. The current transitional government led by Ndayizeye is too occupied fighting for survival to even think about regional integration. Therefore, the only two islands of peace in the region are Kenya and Tanzania. It is, therefore, very difficult to see how a region that is largely in turmoil can move towards a federation, let alone a political union.

Secondly, the fundamental principles of the community seem paradoxically to be working against the establishment of the political federation/union. For example, there is the emphasis on sovereign equality $^{8}$ of the partner states. This seems to work towards consolidating the status quo rather than easing the introduction of a completely new dispensation.

Thirdly, as it has been pointed out, while political federation is identified as the ultimate goal, the process that will bring it about is not specified (Mukandala 2000:100). There is no timetable with clear benchmarks to guide the process. The treaty is silent on the time frame to achieve the federation. While we know the starting point and the end point, it is assumed that the process of getting from one end to the other is obvious. But this is not the case. Whereas the treaty spells out the process of economic integration, that of political integration is not. There is, therefore, a need to develop a clear vision for political federation, regardless of the existence of political will.

Fourthly, structural and institutional obstacles to the free movement of capital, goods and people remain. Specifically talking about the movement of goods, some partner states still practise market protectionism. Recently, Uganda's sugar caused an uproar in Kenya. Members of Kenya's parliament who hail from sugar producing areas were not amused by their government's decision to allow Ugandan sugar on the Kenyan market. These MPs argued that Ugandan sugar was killing the Kenyan sugar market. At one time Ugandan milk was prohibited from entering Rwanda. 


\section{Silver Linings}

Much as the idea of political federation of the region faces great challenges, small strides have been taken towards achieving a politically federated East Africa. The very fact that the treaty of EAC mentions political cooperation is a plus in itself. A look at the treaty that established the defunct EAC reveals that political cooperation was not one of its objectives. Therefore, the prominence that is given to it in the current integration process is a silver lining. This has been amplified and concretised by the political will that the current crop of East African leaders have given towards achieving political integration.

By the end of this year, the leaders of East Africa have committed themselves to signing a protocol establishing a customs union. In fact the Secretariat of EAC is working around the clock to bring this occasion to fruition. ${ }^{9}$ This will be another milestone on the path towards achieving political integration. President Kibaki of Kenya has asserted that 'once the customs union is complete it will be closely followed by the finalization of the instruments for the common market, which include freedom [of movement] of labour and residence across the region'. ${ }^{10}$ Truly, real integration of East Africa is on the way.

In addition, other small steps that have been taken to enhance the integration of the region include the launching of the East African Passport and the East African flag. Others include the establishment of the East African Business Council, and the East African Defence Affairs Unit, among others. It has to be remembered that the framers of the EAC treaty put the private sector and the civil society at the centre of advancing the region's integration. ${ }^{11}$ Small steps they may seem, but these activities have helped to further East African integration. Studies are being undertaken by experts to further harmonise the three countries' foreign and security policies in accordance with the provisions of the treaty.

\section{Conclusion}

The revived integration process of East Africa is trudging along slowly. The legal framework is in place. Institutions have been created and are up and running. By the end of this year it is hoped a fully functioning customs union will be established. The debate on establishing a political federation is going on in the EAC institutions and the respective partner states. However, we would like to warn that political coopera- 
tion should not be hurried. This would help to avoid the problems of integration that the region faced in the past. The suggestion of President Museveni that a union of East and Central African states should be established, much as it sounds a great idea, is not realistic at the moment. The conditions for the establishment of a political federation or union just do not exist, regardless of the existence of the political will on the part of the leaders. Some of the countries involved face monumental problems to even think about regional integration.

\section{Notes}

1. Article 123 (1)

2. The governor of Kenya was the permanent Chairman of the Commission, and he had certain powers to act on behalf of the Commission when it was not in session.

3. For a comprehensive study of the reasons accounting for the failure of the cooperation, see Ojo et al. (1985), African International Relations, London, Longman, pp. 158-71. See also Rwekaza Mukandala (2000), 'Political Cooperation', in Perspectives on Regional Integration and Cooperation in East Africa: Proceedings of the 1st Ministerial Seminar on East African Cooperation, Arusha, Tanzania, 25-26 March, pp. 87-106.

4. In 1978, one year after the break-up of the EAC, the three countries appointed Victor Umbricht to start mediating between themselves on the division of the assets and liabilities of the defunct EAC. He produced two reports in March 1980 and October 1981. The 1984 agreement was based on these two reports.

5. Akiiki Mujaju (1998), 'How to make sense of the events taking place in the Great Lakes Region’, Public Lecture, Department of Political Science, Makerere University.

6. EAC News, August 2002, p. 6.

7. Articles 5 and 123.

8. Article 6 (a).

9. The occasion for the signing of the agreement has been put back to the second half of January 2004.

10. The East African, 22-28 September, 2003, p. 6. See story, 'We must finalize EAC Agreement, says Kibaki'.

11. East African Community, 2nd EAC Development Strategy 2001-5, paras. 4.10.2 and 4.10.3.

\section{References}

Ademola, Y., 1999, Harmonization of Laws in Africa, Lagos: Malthouse Press.

Akiiki, M., 1998, 'How to make sense of the events taking place in the Great Lakes Region', Public Lecture, Department of Political Science, Makerere University. 
Museveni, Y., 1998, Towards a Closer Cooperation in Africa, Kampala.

Ojo et al., 1985, African International Relations, London: Longman.

Rwekaza, M., 2000, 'Political Cooperation', in Perspectives on Regional Integration and Cooperation in East Africa: Proceedings of the 1st Ministerial Seminar on East African Cooperation, Arusha, Tanzania, 25-26 March 1999, pp. 87-106.

The Treaty for the Establishment of the East African Community. 